\title{
REVISITING ROSINANTE: REINTERPRETATIONS OF THE CERVANTINE CHARACTER IN ROSINANTE TO THE ROAD AGAIN, MONSIGNOR QUIXOTE, AND TRAVELS WITH CHARLEY
}

\author{
Ricardo Marín Ruiz \\ Universidad de Castilla-La Mancha \\ Ricardo.Marin@uclm.es
}

\begin{abstract}
This article examines the image of Rosinante given by three of the most relevant writers in the English and American Literature from the $20^{\text {th }}$ century: John Dos Passos, Graham Greene, and John Steinbeck, who approach the figure of this widely-known steed from different perspectives in Rosinante to the Road Again (1922), Monsignor Quixote (1982), and Travels with Charley (1962) respectively. Before undertaking the study of these three interpretations, the first part of the essay deals with some of the features Cervantes conferred on this endearing figure, such as his feebleness and the symbolic dimension which provides Rosinante with the condition of being the only animal having the status of character in Don Quixote. Once these features have been shown, the second part focuses on to what extent the three authors stick to the original conception of Rosinante, and to what extent make personal reinterpretations of this character which often correspond to a critic of different aspects — political, social, economic — of the Western society.
\end{abstract}

KeYwords: Reinterpretation, Rosinante, Dos Passos, Greene, Steinbeck.

\section{RESUMEN}

Este artículo analiza la imagen que de Rocinante ofrecen tres autores claves en la Literatura Inglesa y Norteamericana del siglo xx, como son John Dos Passos, Graham Greene y John Steinbeck, quienes se aproximan a la figura de este célebre rocín desde diferentes perspectivas, como así se puede comporbar en sus novelas Rosinante to the Road Again (1922), Monsignor Quixote (1982), and Travels with Charley (1962) respectivamente. Previa al análisis de estas tres 
interpretaciones, la primera parte del artículo aborda algunas de las características que Cervantes confirió a su personaje, tales como su endeblez y su dimensión simbólica, rasgo este último que lo convierte en el único animal que posee la condición de personaje en Don Quijote. Una vez abordadas estas facetas de Rocinante, en la segunda parte se analiza hasta qué punto los autores seleccionados se ciñen a la concepción original del personaje cervantino y en qué medida lo convierten en objeto de una reinterpretación personal que, a menudo, se corresponde con una crítica de diversos aspectos — políticos, económicos, sociales_ de la sociedad occidental actual .

Palabras Clave: Reinterpretación, Rocinante, Dos Passos, Greene, Steinbeck.

\section{INTRODUCTION}

Don Quixote de la Mancha, the novel written by Miguel de Cervantes in the later period of his life and one of the essential works in Universal Literature, has raised multiple and diverse interpretations; different aspects of this work have been treated from several standpoints in various geographical and intellectual contexts. After having been almost forgotten by critics and readers or, at best, considered merely as a satire of medieval romances, it was in the second half of the $18^{\text {th }}$ century that some English and German writers - Henry Fielding, Daniel Defoe, Lawrence Sterne, Tobias Smollet, Friedrich Schiller, or J.W. Goethe among them - shed light on values, implications, and dimensions of the novel which had been unnoticed until then, such as the symbolism of the work or the idealization of the protagonist (Close, 1978:125). During the $19^{\text {th }}$ and $20^{\text {th }}$ centuries, many authors inside and outside Spain found in Don Quixote not just a memorable literary work, but also a particular conception of life, and more specifically, the essence of the Spanish idiosyncrasy; thus, the protagonist was seen as the incarnation of the sad, inflexible, and hallucinated soul of the inhabitants of Spain (Marín, 2011:115), a perception present in an extensive myriad of writers such as William Wordsworth in The Five-Book Prelude (1799), Wilheim von Humboldt in Prüfung der Untersuchungen über die Urbewohner Hispaniens vermittelst der vaskischen Sprache (1821), Stendhal in De l'amour (1822), Richard Ford in Handbook to Travellers to Spain (1845) Chateaubriand in Mémoires d'outre tombe (1850), August F. Jaccaci On the trail of Don Quixote, being a record of rambles in the ancient province of La Mancha (1896), Havellock Ellis in The Soul of Spain (1908), or Rudolf Lothar in Die Seele Spaniens (1916) among many others. Most of the Spanish intellectuals belonging to the group known as "Generación del 98" found in the melancholic and austere personality of Don Quixote the main features of the Castilian idiosyncrasy and, by extension, of the Spaniards; this is clearly perceptible in authors such as Vicente Azorín in La ruta de don Quijote (1905), and Miguel de Unamuno in Vida de don Quijote y Sancho (1914), who offer a portrait of Castile as an austere and idealist region, and later on in the works of José Ortega y Gasset —such as Meditaciones del Quijote (1914) and España invertebrada (1921)— Menéndez Pidal and Américo Castro in El pensamiento de Cervantes (1925). Nevertheless, the studies concerning the figure of Rosinante ${ }^{1}$, the feeble nag ridden by don Quixote, have been comparatively fewer.

1 See Núñez (1965), who deals with on the symbolic dimension of don Quixote's steed and Sancho Panza's donkey; Fernandez Suarez 1953:149-200; Ordóñez Vila (1968), who focuses on how Rosinante and the donkey share the misfortunes of Don Quixote and Sancho Panza, becoming full-fledged partners in Cervante's satire of chivalric 
For this reason, I think it is important to underline the role played by this loyal and docile horse, whose presence in the novel is, from my view, essential to wholly understand the character of Alonso Quijano; both of them form a unity - just in the same way as Sancho Panza and his donkey do- , where one is the prolongation of the other, sharing values like chastity, generosity, and loyalty. The long series of paintings which have portrayed Don Quixote and Sancho throughout time offers an evidence of the strong ties binding the knight and his squire with their respective animals; in other words, which are the most common images of both characters, those where they appear with Rosinante and the donkey, or those representing them on their own?

Given that in my opinion the role played by Rosinante in many of the interpretations of Cervantes's great novel has been secondary, firstly I will address the singularity of this steed by pointing out those inherent and essential features which, from my view, make Rosinante a particular figure within the wide spectrum of characters in Don Quixote. Secondly, I will focus on how those singular characteristics have been interpreted in three travel books written by some of the most relevant writers in $20^{\text {th }}$ century literature: John Dos Passos's Rosinante to the Road Again (1922), Graham Greene's Monsignor Quixote (1982), and John Steinbeck's Travels with Charley: In Search of America (1962) $)^{2}$. The analysis of these works will show to what extent their authors stick to the original conception and representation of Rosinante in Don Quixote, and how, at the same time, they reinterpret and remake in an unusual and attractive way not only this character, but also certain situations and figures taken from the novel by Cervantes. Finally, with the selection of these works, I intend to give three examples showing how Rosinante is still an influential model for English and American authors who cultivated the genre of travel writing during the last century.

\section{ROSINANTE AND DON QUIXOTE}

A complete understanding of Don Quixote must start in the consideration of the book as a parody of medieval romances. Nevertheless, and according to Riquer, this does not mean that Cervantes intended to mock the chivalric ideals and to aspire to write a superficially "entertaining" work, as it was seen at the beginning of the $17^{\text {th }}$ century (Riquer, 2004:LXXV). Instead, with Don Quijote de la Mancha Cervantes pursued a more serious and transcendental aim than parodying medieval romances; to unveil the archaic and deceitful nature of chivalry books, and by doing so, "deshacer la autoridad y cabida que en el mundo y en el vulgo tienen los libros de caballerías" (Cervantes, 1998:18). The author drew on several resources in order to achieve this goal such as the use of an archaic and pompous style, or the creation of characters which are the degraded and deformed version of the highly idealized of those living in the fabulous and distant — in space and time — world of chivalry books. Thus, Alonso Quijano lives in a place far from being idyllic in a period relatively close to the time

romance; Cull (1990), who studies the comic relationship between the sexually impotent owner and his lascivious horse; Berndt-Kelley (1992), who analyses the representation of Don Quixote and Sancho Panza with beastlike attributes and the treatment of Rosinante and the donkey as humans.

2 The three books will be analyzed in this order to better notice the evolution of the image of Rosinante from a faithful representation, such as Dos Passos's, to a rather free interpretation of the character, as it will be seen in Steinbeck's work. 
when Cervantes wrote his novel and, moreover, he must support the burden of a vulgar and quotidian life; undoubtedly, and as Torrente Ballester states, all these facts induce the reader to think that he is "uno de tantos, uno de nosotros" (1984:18). Many other characters in Don Quixote seem to have gone through the same process of "vulgarization", as all of them correspond to common and typical figures of the Spanish society from the late 1500's and early 1600's. At this point, one could think that those characters which Cervantes adopted from chivalry books to strip them of their extraordinary condition and relocate them in realistic situations are exclusively humans. However, Rosinante is a remarkable exception to this; unlike the rest of the animals — like sheep, bulls, mares, Sancho Panza's donkey, etc.he is the only non-human creature in the novel which is subjected to the above mentioned degrading transformation. Thus, the singularity of this horse does not lie in his strength, bravery or powerful and fast galloping, but in his being deprived of these qualities, just as it happens to human characters.

As Alonso Quijano fervently desires to become a knight-errant, he is conscious of the necessity of obtaining an armor, a new name — don Quixote-, a princess to love, and a horse. The mere acquisition of these elements is not enough to reach the status of knighterrant; the protagonist feels like an authentic knight-errant when he dignifies them, that is to say, when he bestows on them the category of the fantastic and extraordinary. Thanks to his boundless imagination, the nobleman of La Mancha is able to attribute to these beings and objects a series of qualities which are uncharacteristic of them; by doing so, don Quixote reverses the process of "degradation" used by Cervantes to parody chivalry books. This "modus operandi" is noticeable from the first pages of the novel; thus, what the narrator and the reader consider as "unas armas tomadas de orín y llenas de moho" (Cervantes, 1998:41), don Qujixote sees in them the weapons worthy of a knight-errant. Likewise, his extraordinary imagination converts an unattractive peasant woman from the village of El Toboso - Aldonza Lorenzo - in his beautiful queen and lady —Dulcinea. Similarly, the protagonist himself experiences a favorable change when he believes that he has become a warrior. These last two transformations take place through a change of name, which involves for Don Quixote a change of qualities; thus, for example, the election of the name of Dulcinea is not arbitrary, especially taking into account its phonetic similarity with the adjective "dulce" ("sweet"), which refers to a quality characteristic of the beloved lady in the tradition of chivalry books (Torrente Ballester, 1984:57) ${ }^{3}$.

If Cervantes downgrades Rosinante in relation to the horses from chivalry stories, don Quixote follows the inverse process as he is ingenuously convinced that he has changed a nag incapable for military use in "el primero de todos los rocines del mundo" (Cervantes, 1998:42) and attributes it the capacity to determine the direction the protagonist and his squire must follow (Ordóñez, 1968:64). In spite of his powerful imagination, don Quixote is conscious of the real qualities of Rosinante, particularly during the last sally, when his senses are not deceived as easily as in the previous adventures. Thus, the Knight of the Sad Countenance — as he is also known — notices the feeble and tame nature of his horse and understands that the success of his ventures depends on the limited physical strength of his

${ }^{3}$ For further reading, see also Hermann Iventosch, 1966. 
horse (Berndt-Kelley, 1992:592); this is why Don Quixote is stunned by the unusual strength and vigor of Rosinante in his combat with the Knight of the Forest ${ }^{4}$ the only adventure where Rosinante showed these qualities: "Don Quijote, que le pareció que ya su enemigo venía volando, arrimó reaciamente las espuelas a las trasijadas ijadas de Rocinante y le hizo aguijar de tal manera, que cuenta la historia que esta sola vez se conoció haber corridor algo" (Cervantes, 1998:743). This kind of behavior is an exception in Rosinante though; however, don Quixote still finds in his hack several extraordinary qualities which make him superior to mythical and famous horses such as Bucephalus, ${ }^{5}$ Babieca, ${ }^{6}$ Astolfo's hippogryph, ${ }^{7}$ or Bradamante's Frontino. ${ }^{8}$ The significance Cervantes attributes to Rosinante through his connection with the mythical is even bigger than it could be expected at first, especially if one considers that horses hold a prominent position in many mythologies ${ }^{9}$. By doing so, Cervantes provides don Quixote's steed with a high degree of singularity in relation to other animals from the novel ${ }^{10}$. Cervantes makes Rosinante different not only from the rest of the animals appearing in his novel, but also from the legendary horses represented in medieval romances as a way to parody this genre. Thus, whereas those horses represented in chivalry books were worthy of their riders and shared with them qualities such as bravery and elegance, these features are present neither in Rosinante nor don Quixote; however, the important aspect here is not the nature of the qualities they share, but the fact of sharing, since it strengthens the unity and cohesion of the rider-horse binomial.

Besides his idealization, another feature contributing to Rosinante's singularity is his symbolic nature, which justifies the condition as a character, especially if we consider the definition given by the Diccionario de la Real Academia de la Lengua Española: "Cada uno de los seres humanos, sobrenaturales, simbólicos que intervienen en una obra literaria, teatral o cinematográfica" (DRAE, 2014:1739) ${ }^{11}$. Cervantes bestows a symbolic significance on Rosinante when he represents him as the emblem of values and ideals like loyalty, self-denial, and chastity. Don Quixote himself refers to this last virtue as he mentions: "Jamás tal creí de Rocinante, que le tenía por persona casta y tan pacífica como yo" (Cervantes, 1998:163). These words emphasize the close relationship between don Quixote and his nag and their

4 See Part II, chapter 14.

5 Alexander the Great's horse and one of the most famous horses of the Antiquity.

${ }^{6}$ Horse ridden by El Cid, a Castilian nobleman and military leader who lived in the $11^{\text {th }}$ century. He has been traditionally regarded as one of the national heroes of Spain. Since the medieval times, many literary works and chronicles have intermingled history and legend when dealing with this figure, as it is noticeable in works such as: Cantar del Mío Cid (ca. 1195-1207) -the first epic poem in written in Spanish, Crónica de veinte reyes (1284), Crónica de Castilla (1300), Las mocedades de Rodrigo (ca. 1360), Juan de la Cueva's La muerte del rey don Sancho (1579), Guillén de Castro's Las mocedades del Cid (1605), Romancero e historia del Cid (1605), Corneille’s Le Cid (1636), José Zorrilla's La leyenda del Cid (1882), Eduardo Marquina’s Las hijas del Cid (1908), and Vicente Huidobro’s La hazaña del Mío Cid (1929), among others.

${ }^{7}$ A hippogryph is a winged horse. This fantasy creature appears ridden by Astolfo in Ariosto's epic poem The Frenzy of Orlando (1516).

${ }^{8}$ Another of the horses represented in The Frenzy of Orlando.

${ }^{9}$ For example, Núñez states that in Ancient Greece the horse was regarded as the most beautiful and useful animal (1965: 18).

${ }_{10}$ The parodic singularity of Rosinante is even bigger if it is taken into account that in Spanish chivalry literature meaningful names are only given to the protagonists ("Amadís", "Palmerín", etc.) and rarely to horses.

${ }^{11}$ Diccionario de la Lengua Española, 1739. 
parallelisms, which sometimes may be even physical. Throughout the novel, it is possible to observe how the relationship between don Quixote and Rosinante goes beyond the mere analogy and they merge into a unity where one is the necessary complement of the other. They both have to face several hazardous adventures where none of them is able to leave the travel companion, as it is noticeable in the second chapter of Part I, when Rosinante tries to follow his owner to prevent him from going into the deep waters of the Ebro River. In this sense, don Quixote and Rosinante symbolize loyalty, an ideal also embodied in other characters like Sancho Panza and his mule. Excepting very few occasions, such as the protagonist's penitence in Sierra Morena and the adventure of the enchanted boat, don Quixote does not conceive to undertake a new enterprise unless he is accompanied by Rosinante. At the same time, the nobleman is conscious of the faithful spirit of his horse, as we can see, for example, when he addresses Rosinante as "compañero eterno mío en todos mis caminos y carreras" (Cervantes, 1998:47) or as "caballo tan estremado en sus obras" (279).

Don Quixote and Rosinante also embody the ideal of liberty. According to the writer Mario Vargas Llosa, Cervantes's novel is "un canto a la libertad" (2004:XVIII), a facet of the book which is understandable if we bear in mind that it was written by a man who suffered a five-year captivity in Argel and imprisoned in Spain on three occasions; in other words, the unforgettable and painful episodes the author experienced during his lifetime had to spur him to write a work on which he would reflect "un apetito de libertad, y un horror a la falta de ella" (Vargas Llosa, 2004:XIX). In Don Quixote de la Mancha, Cervantes anticipates the same ideal of liberty the liberals would proclaim two hundred years later; liberty understood as sovereignty of the individuals to make their own decisions about their lives without any pressure or restraints. After having left the lands owned by the Dukes, ${ }^{12}$ don Quixote assures his squire that "la libertad, Sancho, es uno de los más preciosos dones que a los hombres dieron los cielos" (Cervantes, 1998:1094). As he asserts this, he feels that he has recovered his liberty, since all the attentions and flatteries from the Dukes had destroyed his initiative, that is to say, his liberty to think and act. Sometimes, the behavior of Rosinante conveys this same ideal of freedom; in spite of his docile and obedient attitude towards his owner, the animal cannot help acting driven by his own instincts. This conduct, which often stems from a sexual desire, causes Rosinante to disobey don Quixote's orders, and consequently betray the confidence he put in his horse. This situation is clearly noticeable in two episodes. The first of them is the adventure of the Yanguesans. On this occasion, the animal instinct prevails on Rosinante as he tries to mate the mares driven by the Yanguesans in spite of don Quixote's warnings; this behavior has terrible consequences for Rosinante and his owner, since it causes them to be battered by the Yanguesans. The second takes place in the inn. ${ }^{13}$ In this episode, don Quixote is hanging from a grill after having been deceived by Maritornes and the innkeeper's daughter. Fortunately, at first he can solve this embarrassing situation by laying his feet on the back of Rosinante. However, although at that moment don Quixote trusts the patience and quietness of his nag in order to avoid a painful fall, Rosinante is driven once again by his primary instincts and leaves don Quixote alone:

Sucedió en este tiempo que una de las cabalgaduras en que venían los cuatro que llamaban se llegó a oler a Rocinante, que, melancólico y triste, con las orejas caídas, sostenía sin moverse a su

${ }^{12}$ See Part II, chapter 57.

${ }^{13}$ See Part I, chapter 43. 
estirado señor; y como en fin era de carne, aunque parecía de leño, no pudo dejar de resentirse y tornar a oler a quien le llegaba a hacer caricias y, así, no se hubo movido tanto cuanto, cuando se desviaron los juntos pies de don Quijote, y, resbalando de la silla, dieran con él en el suelo, a no quedar colgado del brazo, cosa que le causó tanto dolor, que creyó o que la muñeca le cortaban o que el brazo se le arrancaba. (Cervantes, 1998:511)

These two episodes exemplify how liberty creates discord between don Quixote and Rosinante. Nevertheless, both of them are two sides of the same coin; the former symbolizes the conscious dimension of the human psyche, whereas the latter represents the unconscious, like the rest of animals ${ }^{14}$. Thus, Cervantes includes Rosinante within the sphere of the human; by doing so, the author aims for two objectives: on the one hand, he tries to show how pernicious it may be for the individual to be drawn by the instincts and, on the other, he intends to get a humorous effect by attributing to Rosinante some traces of human behavior. Regardless of the ridiculous connotations of this "humanization" of Rosinante, we should see in this characterization a serious determination to vindicate his status as a character. In fact, don Quixote addresses his horse in the adventure of the Yanguesans as "persona", a word of Latin origin Cervantes employs implicitly with its etymological meaning of "character". Likewise, in a sonnet included at the beginning of the book, the author represents Rosinante with some human features in the dialogue held with Babieca, a resource he would also use in the novel El coloquio de los perros (1612).

To sum up, the features conferring a certain degree of singularity on Rosinante are mainly two: firstly, the condition of being the only animal to be subjected to the process of "degradation" Cervantes carries out to parody the genre of chivalry books and, secondly, his status as a character. Having considered these qualities, the following section will show to what extent they are represented either unchanged or transformed in the interpretations John Dos Passos, Graham Greene, and John Steinbeck made of Don Quixote de la Mancha.

\section{VISIONS OF ROSINANTE IN JOHN DOS PASSOS, GRAHAM GREENE, AND JOHN STEINBECK}

Throughout his literary career, John Dos Passos wrote several travel books in which he reflected his experiences during his travels in North America, the Middle East, and Europe. One of his favorite destinations was Spain, where he found a culture which had fascinated him since he was a teenager; then, it is not surprising that he visited this country on three occasions between 1916 and the outbreak of the Spanish Civil War in 1936. His second travel to Spain, in 1919, was the main source of inspiration of Rosinante to the Road Again, a title which may be misleading, as the subject matter of the book is not Rosinante, but the trip on foot of Telemaco from Madrid to Illescas (Toledo). The protagonist meets a variety of people on his way; one of them is don Alonso, whose name and physical features clearly remind the reader of don Quijote: he was "full of little lines like an over-ripe tomato and a

${ }^{14}$ According to Carl Gustav Jung, the animal represents the non-human psyche, the subhuman instinctive, and the unconscious psychic side (Cirlot, 1991: 73). 
long bloodless face drawn into point at the chin by a grizzled beard" (Dos Passos, 2008:73). As if that were not enough, don Alonso rides "a grey sway-backed horse that joggled in a little trot with much switching of a ragged tail” (Dos Passos, 2008:72), a steed which almost automatically suggests the figure of Rosinante. Dos Passos also alludes to Sancho Panza and his complementary role by representing don Alonso accompanied by "man on a donkey who was shaped like a dumpling" (2008:72-73).

The intertextual relationships between the works of Cervantes and Dos Passos do not only concern physical similarities, but also other aspects such as the fact that don Alonso was born in La Mancha or his chivalrous ideals: "Many years ago I should have set out to right wrong - for no one, but a man, an individual alone, can right a wrong" (Dos Passos, 2008:75). The analogies of Rosinante to the Road Again with Don Quixote are so easy to identify that if the reader did not know the names of don Alonso and his partner, it would instinctively call them don Quixote and Sancho Panza; this is what happens to Telemaco, who guesses - although he will never know - that the name of the horse is Rosinante, due to their surprising likeness with the characters of Cervantes: "I wonder what his name is. [...] Is it Rosinante?" (Dos Passos, 2008:79). In fact, on asking don Alonso whether the horse liked figs or not, Telemaco addresses it as Rosinante: "I'm sure the Spartans ate figs on the road. Will Rosinante, I mean, will your horse eat them?" (Dos Passos, 2008:233). His feeble and sickly appearance makes this horse a faithful reproduction of don Quixote's horse, a circumstance which indirectly links the animal depicted by Dos Passos to the abovementioned process of degradation underwent by the characters from chivalry books in Don Quixote.

The similarities between Rosinante and don Alonso's horse are only physical. Thus, the latter lacks the symbolic dimension of the former and, according to the previously given definition of character, Dos Passos does not regard "his" horse as such. In the view of the American author, the steed is a mere prolongation of the ideals of justice, sobriety, and effort embodied by don Alonso. Dos Passos finds in these values the key to finish with the social, political, and moral decadence of Spain at the beginning of the last century, which is attributed to what the author calls "the gospel of Sancho Panza", that is to say, "the easy acceptance of life, the unashamed joy in food and color and the softness of women's hair" (2008: 70). However, this "gospel" of apathy and unconcern is so deeply rooted in the spiritual tissue of the country that in Dos Passos's view it is almost impossible to conceive a modern Spain with a morality based on the ideals laying in the figures of Don Quixote and Rosinante; indeed a pessimistic view which pervades the book and, in my opinion, makes the author feel the same apathy and passivity of the Spanish society to such an extent that he finds any attempt of Don Quixote and Rosinante to set on a new journey bound to fail; this would explain the reason why Dos Passos tries to penetrate in Don Quixote's mind and know the reason of a hypothetical new adventure: "And I wondered to what purpose it would be, should Don Quixote again saddle Rosinante" (2008:70).

Although it was published in a period of dramatic changes in Spain - the democratic transition, Graham Greene's Monsignor Quixote portraits a country still trapped in stereotypes from the past. In fact, the image of Spain here is not very different from those offered, for example, by George Orwell in Homage to Catalonia (1938), Ernest 
Hemingway in For Whom the Bell Tolls (1940), or Gerald Brenan in The Spanish Labyrinth $(1943)^{15}$. Thus, in Greene's vision, Spain continues to be associated with topics like poverty, backwardness, individualism, pride, and disorganization, which make the country progress as slowly as the old car of Monsignor Quixote. But in my view, this revisiting of secular stereotypes is not the most interesting and specifying feature of Greene's work, but what Graham Holderness calls the sustained intertextual relationship with Cervantes's novel $(1993: 262) ;{ }^{16}$ as it is noticeable in the title of the book, the main characters here are named after those from Don Quixote, although in this case they are not a knight and his squire, but a priest and a former major of the village of El Toboso. Greene introduces further references to Don Quixote throughout his book; thus, for example, Monsignor Quixote considers himself as a descendent of Alonso Quijano when he baptizes his car with the name of Rosinante: "As he drove he worried about the fate of the Seat which he called in memory of his ancestor "my Rosinante"' (Greene, 1982:11). Likewise, Greene changes Teresa, Sancho Panza's wife, into the housekeeper of the church of El Toboso, and Father Herrera reminds of the cervantine character of Sansón Carrasco.

Further examples of allusions to Don Quixote could be listed, but here we are going to focus on those parallelisms concerning the figure of Rosinante. Like many other characters in Monsignor Quixote, Rosinante inherits the main features of his "counterpart" in Cervantes's work; as we could see above, in Monsignor Quixote Rosinante is an old and shabby car, that is to say, an unanimated being with some of the distinctive attributes of don Quixote's steed; thus, Greene focuses on those features of Rosinante derived from the degrading process employed by Cervantes to parody chivalry books. In Monsignor Quixote, the feeble and sickly health of Rosinante is turned into the obsolete mechanics of an old Seat 600 . The poor state of the vehicle results in several accidents, breakdowns, and an extraordinary slowness. The low speed of Rosinante draws the attention of two agents of the Guardia Civil. Greene seems to know the negative connotations of this institution in Spain and identifies them with the windmills of Don Quixote, as we can see, for example, when Sancho talks to Monsignor about the two agents: "It wasn't until he left his village that your ancestor encountered the windmills. Look. Our task is easier. We have not thirty or forty windmills to encounter, we have only two" (Greene, 1984:96). Later on, once the agents have been left behind, Sancho feels that Monsignor and himself "have conquered the windmills" (Greene, 1984:103). The reader could judge from these words that the protagonist, just like his ancestor, has "spurred" Rosinante and charged against his particular "giants" — the agents — to defeat them; however, the Guardia Civil is a constant threat for Monsignor and his partner, who always try to shun the agents. Curiously enough, Rosinante is regarded here as a horse rather than a car, since Dos Passos describes its struggle for escaping by itself from the Guardia Civil, as if the automobile were a living creature. With this particular characterization of Rosinante, the author does not intend to amaze the reader as much as to create a strategy which enhances

${ }^{15}$ For a detailed analysis of the image of Spain in Homage to Catalonia and For Whom the Bell Tolls, see "Autor", 2011:255-358. See also "Autor" 2012.

${ }^{16}$ Besides the evident and almost explicit references to Don Quixote, Holderness (1993:276) also finds in Greene's novel less noticeable kinds of literature: scriptural, theological, devotional, ethical —St. Augustine, St. John of the Cross, St. Teresa, St. Francis of Sales, Father Caussade, etc. A Catholic literature which constantly in dialectical relationship with the classics of Marxist doctrine, especially The Communist Manifesto. 
the strong parallelisms between Monsignor's car and don Quixote's steed, and reinforces the unity and coherence of the narration, since Rosinante is provided with animal-like features throughout the work; thus, at the beginning of the book, the narrator states that Monsignor "was more likely to receive a favorable answer if he spoke of Rosinante as a horse" (Greene, 1984:19). Later on, Monsignor continues to address his car as if it were an animal, so the reader often envisions Rosinante as a living creature which pants and gets tired - "the heavy panting of a tired Rosinante" (Greene, 1984:93) groans - "Rosinante groaned when the gears changed" (Greene, 1984:112) and moves like a horse, a circumstance clearly noticeable through the use of the term "skittish", an adjective often employed in relation to horses: "Rosinante was positively skittish after her stay in the garage" (Greene, 1984:141). Then, it is clear that Monsignor sees in his car an animal, and more specifically, a horse, and this to such an extent that he believes Rosinante has the capacity to make decisions and show a rebellious attitude, which reminds of the behavior of don Quixote's steed in the adventure of the Yanguesans: "For an inexplicable reason Rosinante put on a spurt of speed instead of slowing down" (Greene, 1984:55).

This is, however, the only occasion when Monsignor's Seat 600 reaches a reasonable speed. Despite the negative connotations of slowness in modern societies, Monsignor finds in the slow pace of Rosinante an advantage instead, since it allows him to experience a real journey, that is to say, a journey where distances are relativized and the really important thing is to savor every kilometer:

The slowness of Rosinante made a nonsense of distance. Well, the furthest that his ancestor had gone from La Mancha in all his journeys had been the city of Barcelona and yet anyone who had read the true history would have thought that don Quixote had covered the whole immense area of Spain. There was a virtue in the slowness which we had lost. Rosinante was of more value for a true traveler than a jet plane. Jet planes were for business men" (Greene, 1984:106).

This way of travelling provides Monsignor with a sense of liberty. Although he must grapple his journey along with handicaps such as the Guardia Civil or the constant recriminations and censorship of the bishop of Toledo, Monsignor sees in his journey the possibility to escape from a society more and more modernized whose members live under the tyranny of schedules. He finds in his wandering around Spain the manifestation of the ideal of liberty conceived by Cervantes more than three hundred years earlier; the capacity to impose one's will when acting and/or thinking. In Greene's novel, Monsignor behaves like this, as it is him who freely sets the course of his journey.

According to the definition of "character" given by the DRAE, Monsignor Quixote's car is treated like a character on the grounds that it is the symbol of friendship and loyalty. In Greene's book, the relationship of Rosinante with freedom is clear if we bear in mind its condition as a means which enables Monsignor to leave behind his monotonous life in El Toboso, and set off on a journey with no predetermined destinations. With regard to the idea of loyalty, it is interesting to see how Greene pictures Rosinante as a faithful fellow traveler whose mechanical problems do not prevent it from taking its owner to those places he wants to visit. In spite of the continuous setbacks caused by the "weakness" of Rosinante, Monsignor does not show an attitude of scorn or annoyance towards his Seat 600, but, on the contrary, he understands that the feebleness of the car is the logical consequence of its 
loyal service throughout so many years. Monsignor rewards the staunchness of Rosinante with continuous care and neverending concern about its mechanics, as we can see, for example, when the protagonist warns Sancho not to overstrain the old engine of the car (Greene, 1984:231). With the reciprocal loyalty between Monsignor and Rosinante, Greene intends to draw the reader's attention to the fact that both of them must be seen as a whole. The author hints at their unity, for example, through the deep knowledge Monsignor shows about Rosinante when he states: "Rosinante has certain tricks of its own which only I know" (1984:43). Later on, the reader can see how the fusion between man and machine even finds a material expression in the passenger's seat, which has adopted the shape of Monsignor's buttocks: "The seat had been shaped by his body through the years and its shape was as familiar to him as the curve of the saddle had been to his ancestor" (Greene, 1984:44). However, it is in the last pages of the book where the relationship between Monsignor and Rosinante has its most evident and emotive expression, more specifically when Monsignor, shortly before his death, knows that his car is "resting" in the garage. It is then the protagonist feels that his adventures are over, because Rosinante is about "dying" and he is unable to conceive a new trip without his old car; all in all, Monsignor is aware that both of them are old and that they are in the dusk of their lives. It is interesting to point out here how the symbiotic relationship between them lasts until the very last second of their existence, since they die nearly at the same time. Their fates are in an almost geometrical parallelism, till the moment of death, a circumstance which in my view must be interpreted as the ultimate manifestation of the cohesion and empathy which had characterized their relationship. The synchrony in the lives and deaths of Monsignor and Rosinante astonishes Sancho and makes him ponder about one of the main lessons of the book, that human beings are machines too:

There was no more of a future for Rosinante than for Father Quixote. They had died within a few hours of each other - a broken mass of metal, a brain in fragments. He insisted with a kind of ferocity on the likeness, fighting for a certainty: that the human being is also a machine. But Father Quixote had felt love for this machine (Greene, 1984:255).

In Travels with Charley, John Steinbeck recalls his journey around the United States from September 1960 to January 1961 with the goal of knowing personally the condition of the country he had written about so often. The American author started his particular adventure in Long Island, New York, followed the border from Maine to the Pacific Northwest, visited Salinas, his hometown in California, and afterwards drove across Texas, the Deep South, and then back to New York. Throughout this 10,000 mile travel, Steinbeck realized that in the early 60's there was no trace of the American society he had portrayed in novels like The Grapes of Wrath (1939) or The East of Eden (1952).

John Steinbeck drove around his native country in a motorhome called "Rosinante". Perhaps this name was due to the way the writer devised the true journey, that where the traveler, like don Quijote in his adventures, sets out with no certain destination: "A journey is a person itself; no two are alike. And all plans, safeguards, policing, and coercion are fruitless. We find after years of struggle that we do not take a trip; a trip takes us" (Steinbeck, 1984: 4). The journey, then, is quixotic in its conception, but its protagonists hardly resemble the characters from Don Quixote; more particularly, the similitudes between Rosinante and its ancestor are fewer and more complex than in Rosinante to the Road Again and Monsignor 
Quixote. To begin with, in Steinbeck's book, Rosinante is not a skinny and feeble steed, but "a tough, fast, comfortable vehicle, mounting a camper top - a little house with double bed, a four-burner stove, a heater, a refrigerator and lights operating on butane, a chemical toilet, closet space, storage space, windows screened against insects - exactly what I wanted" (Steinbeck, 1984:6). The contrast of this new-brand motorhome is evident not only with the don Quixote's unhealthy steed, but also with the emaciated horse depicted by Dos Passos and the old Seat 600 driven by Monsignor Quixote. It is true that Greene and Steinbeck identify Rosinante with vehicles, but even so the differences between these two versions outnumber the similitudes. Firstly, Steinbeck does not travel in an old and shabby automobile whose mechanics are in a very bad condition, but, as we have seen before, in a fully equipped roulette; thus, in this case the author suggests an image of the famous steed devoid of those features Cervantes bestowed on Rosinante as a result of the process of degradation abovementioned. Secondly, and as a consequence of this, only in Travels with Charley we can see how Rosinante arouses the admiration of those people his owner finds on his way, like the day laborers of Maine, who observed the roulette "with admiration" (Steinbeck, 1984:66), or the Indian from North Dakota, whose eyes seemed to pop out as he stared at Rosinante: "I pulled up to speak to him, saw his eyes wash over Rosinante, sweep up the details, and then retire into their sockets" (Steinbeck, 1984:154).

These distinctive and particular features of Steinbeck's version of don Quixote's steed must not overshadow the existence of some characteristics which are also present in the more faithful reinterpretations carried out by Dos Passos and Greene and, consequently, stem from certain features of Cervantes's character. Like Monsignor Quixote's car, sometimes the motorhome driven by Steinbeck is represented as an animal which resembles more its ancestor and its analogous figure in Rosinante to the Road Again than a machine. This process of animalization in Travels with Charley must be interpreted as a strategy to take the allusions to Don Quixote further than the mere onomastic reference; if we consider this circumstance, it should not be surprising to find throughout the book situations where the roulette "behaves" as a horse, which "leaps over the road with joy" (Steinbeck, 1984:62), or whose overloaded springs "cry with anguish" (Steinbeck, 1984:154). Another feature which gets Steinbeck's version closer to the cervantine character is the fact that both of them are held in high esteem by their respective owners, as we can clearly notice when Steinbeck recalls the perfect performance of Rosinante during his stay in Oregon: "the gallant Rosinante bespoke my attention. I have not spoken of my faithful vehicle except in formal terms of passing praise ... If Rosinante has been neglected in this account, it is because it performed perfectly" (1984:183). A third nexus among Steinbeck's vision and those we can find in Rosinante on the Road Again and Monsignor Quixote is the existence of a symbolic dimension. Like Cervantes and Greene, the author of Travels with Charley identifies Rosinante with ideals which make it a symbol. As we have seen before, Steinbeck emphasizes the loyalty of his roulette, one of the distinguishing features in the behavior of the famous horse. Then, Steinbeck attributes to his vehicle values present in don Quixote's steed, however, the axiological meaning of Rosinante in this novel is not only made up of the ideals embodied by its ancestor, but also of those coming from Steinbeck's personal interpretation; thus, while it is difficult to see Rosinante as a model of protection in Don Quixote, the American author conceives "his" Rosinante as a "turtle shell" (Steinbeck, 
1984:7) which protects him, for example, from the gunshots of the hunters who prowled in Maine. Nevertheless, Steinbeck considers that the worst and true threat is not the stray bullets, but the American society itself, which progress has dramatically changed for the worse. At the beginning of the travel, Steinbeck is aware that the society he lives in is in permanent transformation - "There are customs, attitudes, myths and directions and changes that seem to be part of the structure of America" (1984:56)—, he seems not to suspect about the fatal consequences of these transformations. Much to his regret, the author is conscious that he is not under the effects of an enchantment - as don Quixote believed to be- when he realizes that his society has become more and more unsatisfied and dehumanized. Just like don Quixote, Steinbeck has also the chance to fight against the windmills, which in this case correspond to the manifestations of a crumbling society: cities turned into concrete jungles, service areas crammed with vending machines full of unhealthy and tasteless products, the disappearance of local accents, the lack of communication, etc. However, he decides not to charge into the windmills as he regards them unlikely to be defeated. It is at this critical moment of resignation and frustration that Steinbeck finds in Rosinante not a means of attacking the windmills, but a cozy shelter to escape from them; this is noticeable, for instance, during his stay in a hotel in New England, whose extremely hygienic conditions are a synonym of dehumanization:

In the bathroom two water tumblers were sealed in cellophane sacks with the words: 'These glasses are sterilized for your protection'. Across the toilet seat a strip of paper bore the message: 'This seat has been sterilized with ultraviolet light for your protection'. Everyone was protecting me and it was horrible ... Then I lay deep in hot water in the tub and I was utterly miserable, and nothing was good anywhere (1984:47).

Although paradoxical it may seem, this environment is overwhelming for the protagonist and he finally decides to return to Rosinante, where he feels he can still live protected from the sweeping corrupting effects of a voracious and inhuman modernization.

Rosinante is also a symbol of humanity and liberty. Sometimes, the roulette becomes the place where his owner meets individuals who belong to some of the marginal groups in the American society; this is the case, for instance, of the Canadian immigrants Steinbeck hosts in his motorhome. The friendly and outgoing character of these seasonal workers, who crossed the border every year to harvest potatoes in the US, creates within Rosinante an atmosphere of brotherhood which, according to Steinbeck, was then almost inexistent in human relationships: "The cognac was very, very good, and from the first muttered 'Santé' and the first clicking sip you could feel the Brotherhood of Man growing until it filled Rosinante full -and the Sisterhood also" (1984:69). Steinbeck's vehicle is also shown as a shelter for the underprivileged during his stay in New Orleans; there he witnesses the racial incidents which spread over the city after some parents had refused to send their children to study with black students in one of the local schools. The author soon sympathizes with those who were discriminated for the sake of their skin's color as we can see, for example, when he picks up an untrusting elderly black man and, afterwards, a young student astonished by the fact that a white man let him in his motorhome:

I picked up one more passenger between Jackson and Montgomery, a young Negro student with a sharp face and the look and feel of impatient fierceness ... I knew he was a student because 
I asked him. He was alert. License plate and speech relaxed him as much as he is ever likely to relax (1984:270).

Like Cervantes and Greene, Steinbeck associates Rosinante to the idea of liberty. In Travels with Charlie, the roulette is represented as the essential condition for the protagonist to travel freely around the country and flee from a way of life corrupted by strict social rules and conventions. At the beginning of the second part of the book, Steinbeck reveals his intention to set on a journey in order to leave temporarily behind the conventional existence he shared in New York with his wife and friends:

As the day approached, my warm bed and comfortable house grew increasingly desirable and dear wife incalculably precious. To give these things up for three months for the terrors of the uncomfortable and unknown seemed crazy ... I could get sick, of course, but that was one of my main but secret reasons for going at all. During the previous winter I had become rather seriously ill with one of those carefully named difficulties which are the whispers of approaching age. When I came out of it I received the usual lecture about slowing up, losing weight, limiting the cholesterol intake. It happens to many men, and I think doctors have memorized the litany. It had happened to so many of my friends (1984:19).

Likewise, Steinbeck manifests his desire for liberty through his determination to drive only on secondary roads and shun the monotonous and never ending highways, which were as uniform and dehumanized as the people who constructed them: "I stayed as much as possible on secondary roads where there was too much to see and hear and smell, and avoided the great wide traffic slashes which promote the self by fostering daydreams" (1984: 95). Later on, the author refers to secondary roads as ways of escape from the chaotic development in which the country lived immersed:

As I passed through or near the great hives of production - Youngstown, Cleveland, Akron, Toledo, Pontiac, Flint, and later South Bend and Gary - my eyes and mind were battered by the fantastic hugeness and energy of production, a complication that resembles chaos and cannot be ... What was so wonderful was that I could come again to a quiet country road, tree-bordered, with fenced fields and cows, could pull up Rosinante beside a lake of clear, clean water and see high overhead the arrows of southing ducks and geese (1984:108).

\section{CONCLUSION}

The preceding study of the image of don Quixote's horse in Rosinante to the Road Again, Monsignor Quixote, and Travels with Charley confirms the persistence in these works of those features conferring Rosinante a special singularity among the wide variety of characters from Don Quixote. In my view, such particularity can be found in two qualities: firstly, in his condition as the only animal in this novel which partakes in the process of "degradation" employed by Cervantes to parody chivalric books and, secondly, in the symbolic dimension which provides the famous horse with the status of character. The interpretations made by Dos Passos, Greene, and Steinbeck also differ significantly. Thus, whereas the first two authors draw the reader's attention to the feebleness and unhealthy condition of Rosinante, Steinbeck focuses on features which go beyond the reader's senses 
and diminishes the importance of the similitudes between the roulette and don Quixote's horse. It is also interesting to notice, on the one hand, how Greene and Steinbeck consider their respective "Rosinantes" as characters, that is to say, as symbolic figures which embody the same values as their ancestor, such as loyalty and liberty; on the other, in Dos Passos's interpretation, Rosinante lacks that symbolic nature and is a mere prolongation of the knightly ideals of its owner, such as justice, sobriety, and effort.

Those features which are identical to, or at least resemble, some characteristics of don Quixote's horse do not only emerge from a process of imitation, but also of adaptation, where each author, as we have seen, introduces changes in relation to both the process of "degradation" present in Cervantes's novel and the status of Rosinante as a character. Sometimes, this interesting symbiosis between imitation and adaptation results in quite particular views, which are, in my opinion, closer to the concept of subjective interpretation rather than that of mimesis. This is especially noticeable in Monsignor Quixote and Travels with Charley. In the former work, Rosinante is an old car with almost endless mechanical breakdowns which, in some sense, remind of the sickly and unhealthy condition of don Quixote's horse, whereas the latter shows a more transgressing and less faithful vision of Rosinante as a brand new and comfortable motorhome which does not resemble at all the weakness of its ancestor. In this sense, it could be assumed that Greene and Steinbeck's images of Rosinante are rather free visions of the original; nevertheless, if their symbolic nature is regarded, they must be seen as faithful interpretations, since we find in them the same values and ideas - loyalty and freedom mainly - which Cervantes bestowed on his character. This preservation of the timeless and universal values constituting the symbolic dimension of Rosinante must be attributed to an interest in assessing their current state in modern societies, where dramatic changes — whether political or ecomomic - have undermined the strength and consistency of human relationships and have not prevented many individuals from being deprived of fundamental rights and liberties.

\section{BIBLIOGRAPHY}

Berndt-Kelley, ERna (1992): "En torno a sus bestias y a ser bestias", in Vilanova, A. (ed.), Actas del X Congreso de la Asociación Internacional de Hispanistas, Barcelona, AIH, pp. 589-596.

CAstro, Américo (1980): El pensamiento de Cervantes, Barcelona, Noguer.

Cervantes, Miguel de (1998): Don Quijote de la Mancha, Francisco Rico (ed.), Barcelona, Crítica.

Chateaubriand, François-Rene Vicomte de (1984): Mémoires d'outre tombe, Paris, Librairie Générale Française.

Cirlot, JuAn E., (1991): Diccionario de símbolos, Barcelona, Labor.

Close, Anthony (1978): The Romantic Approach to Don Quixote. A Critical History of the Romantic Tradition in "Quixote" Criticism, Cambridge, Cambridge University Press.

Cull, John T. (1990): "The Knight of the Broken Lance and His Trusty Steed: On Don Quixote and Rocinante", Revista Cervantes, 2, pp. 37-52.

Dos Passos, John (2008): Rosinante to the Road Again, Whitefish, Kessinger Publishing.

Ellis, Havelock (2008): The Soul of Spain, Whitefish, Kessinger Publishing.

Fernández SuÁrez, Álvaro (1953): Los mitos del Quijote, Madrid, Aguilar.

Ford, Richard (2012): Handbook for Travellers in Spain, Charleston, Nabu Press. 
Greene, Graham (1982): Monsignor Quixote, Harmondsworth, Penguin Books.

Holderness, Graham (1993): “'Knight Errant of Faith'?: Monsignor Quixote as 'Catholic Fiction'”, Literature and Theology, 7.3, pp. 259-283.

Humboldt, Wilhem von (2014): Prüfung der Untersuchungen über die Urbewohner Hispaniens vermittelst der vaskischen Sprache, Charleston, Nabu Press.

Iventosch, Hermann (1966): "Dulcinea, nombre pastoril”, Nueva Revista de Filología Hispánica 17, pp. 60-81.

JaCacci, August F. (2013): On the Trail of Don Quixote, Being a Record of Rambles in the Ancient Province of La Mancha, New Dheli, Gyan Books.

Lothar, Rudolf (2013): Die Seele Spaniens, New Dheli, ReInk Books.

“AutoR" (2011): La imagen de España durante la guerra civil en L'espoir, Homage to Catalonia y For Whom the Bell Tolls, Murcia, Nausicaa.

- España según Malraux y Orwell (2012): Saarbrüecken, Editorial Académica Española.

Martínez Ruiz, José, “Azorín” (2005): La ruta de don Quijote, Ciudad Real, Artelibro.

Núñez, Francisco M. (1965): Rocinante y rucio. Dos tesis, San José, Lehmann.

Ordóñez Vila, Montserrat (1968): "Rocinante y el asno, personajes cervantinos", Razón y Fábula 8, pp. 57-75.

OrTEga y Gasset, José (2001): España invertebrada, Madrid, Alianza.

- (2005): Meditaciones del Quijote, Madrid, Alianza.

RAE (200 I): Diccionario de la Real Academia de la Lengua Española, Madrid, Espasa.

Riquer, Martín De (2004): "Cervantes y el Quijote", in Cervantes, Miguel de, Don Quijote de la Mancha, ed. Francisco Rico, Madrid, Alfaguara, pp. XLV-LXXV.

Stendhal (2001): De l'amour, Paris, Gallimard.

Steinbeck, John (1984): Travels with Charley: In Search of America. Harmondsworth, Penguin Books.

Torrente Ballester, Gonzalo (1984): El Quijote como juego y otros trabajos críticos, Barcelona, Destino.

Unamuno, Miguel de (2005): Vida de don Quijote y Sancho, Madrid, Cátedra.

Vargas Llosa, Mario (2004): "Una novela para el siglo XXI", in Cervantes, Miguel de, Don Quijote de la Mancha, ed. Francisco Rico, Madrid, Alfaguara, pp. XIII-XXVIII.

Wordsworth, William (1997): The Five-Book Prelude, Blackwell, Hoboken. 